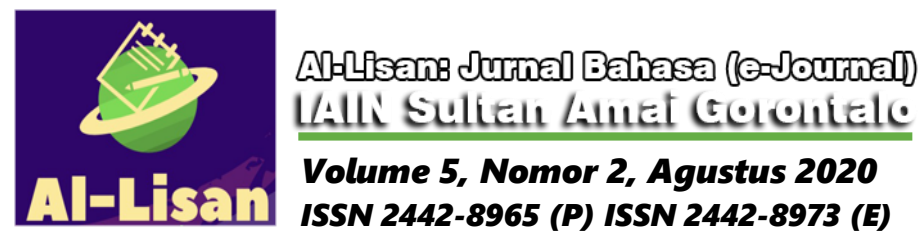

\title{
Students' Perceptions of Using Machine Translation Tools In the EFL Classroom
}

\author{
Sujarwo \\ jarwo.ibrahim@gmail.com \\ Universitas Megarezky, Indonesia
}

\begin{abstract}
Machine Translation (MT) refers to automatically trying to translate words, phrases, text, or speech from one language to another (Arnold et al., 1994). This study aims to analyze English as Foreign Language (EFL) students' perceptions on utilizing machine translation (MT) in translating words, phrases, text, or speech. This research used descriptive qualitative method, 13 EFL students as respondents using this type of technology were described and analyzed. Data were gained from the analysis of the translation quality supported by machine translation procedures and questionnaires to 13 English students in translation subject. The results showed that, EFL students in the sixth and seventh semester of English education department of Megarezky University in translating words, phrases, texts, paragraphs had to recheck and rearrange to get a good translation by their own understandings. Machine Translation (MT) becomes another option to recognize the meaning of foreign language. Machine Translation can be used as dictionary as well. MT is incredibly useful and helpful, it can provide a general description to the users, it gives an inspiration or consideration to the users to understand the meaning.
\end{abstract}

Keywords: EFL students' perception; Machine Translation tools.

\section{A. INTRODUCTION}

When the machine translation became on the market online, it has drawn the attraction of professional translators and different communities. There have been discussions for its attainable implication to their desires. The translation community's adoption of machine translation had been undertaken by several researchers in numerous countries from the start of the 2000s (Bhattacharyya \& Jha, 2016). Machine Translation (MT), which refers to the attempt to automate the process of translating text or speech from one language to another, and it has become the leading technology in the 


\section{Sujarwo}

current age of information technology (Arnold et al., 1994). As the demand for translation has increased tremendously, MT is now widely used worldwide (Almutawa \& Izwaini, 2015 as cited in Sabtan, 2020). Within the past, language learners used a dictionary to induce meanings of unknown words within the target language. Looking up, traditional dictionaries are time-consuming, and L2 learners might get any difficulties in interpreting the meaning of some words.

Nowadays, a world of omnipresent Wi-Fi connections, laptops, tablets, smartphones, foreign language teachers or lecturers, and students has fingertips a broad collection of free online resources for translators (FORTs), including powerful of MT websites and apps. These online resources have made life easier than before (Alkhatnai, 2019). For this purpose, previous investigations on the use of MT for EFL teaching and learning are explored before discussing their implications for the language class along with some practical examples of using MT for language teaching purposes. The article concludes with the results of a survey study about the perceptions of language learners and language tutors on the use of MT and free online MT for language tuition.

With the advanced and innovative development of information and communication technologies (ICTs), various Internet-based tools such as Facebook, wikis, and blogs provide a social and interactive platform on which students have more opportunities to practice their writing, create discussion, share their thoughts, and receive instant feedback - formal or informal - to their writing. Google, used as an online corpusderived engine, has also been widely used for quick and straightforward information searches (Tsai, 2019). All the contributions to technology's theoretical and empirical aspects are implemented in pedagogy for second instruction and translation studies. The very fact that new tools area unit seldom among the creation of recent teaching and coaching approaches is remarked upon, as an excessive amount of recent effort has been placed into tools and deficient has been dedicated to dynamic teaching strategies and approaches (Warschauer and Meskill 2000 as cited in (Carrió-Pastor, 2016).

Perception is also recognized as a process of receiving, selecting, organizing, interpreting, testing, and giving a reaction to an object, event, or problem (Davidoff, 1998). Perception is a process that is preceded by sensing, which is a stimulus received by an individual through a receptor, namely the senses. Studies show that student perceptions are crucial factors of student behavior, and it may be a basis for designing 


\section{Sujarwo}

the teaching model that optimizing the training outcomes. Students' perceptions reflect how, why, and what students learn. The other studies show that investigation on student perception is crucial in EFL teaching. In other words, the period when paper dictionaries dominated the reference world has gradually expired and e-dictionaries rather than traditional paper products have eventually become prominent in word reference and Nowadays, in an era of internet and new media technology expansion, digital dictionaries are well under way of development and popularity (Jin \& Deifell, 2013 as cited in Le \& Dao, 2019).

As previously stated, the aim of this study is to research the student's perception on translation. The student has totally different opinions regarding the course, its content and objectives, the level of issue, the time students invested with inside the course, adults' learning, and the teacher's role. Wang also suggests that translation is a useful gizmo or tool in learning, and there should be more translation exercises. However, such perceptions correspond to a frequently reported premature bias, which may a minimum of partly disappear as students start interacting with MT and understand how it works (Rossi \& Chevrot, 2019).

As Hutchins says, an MT is that the software related to computer systems within the interpretation of text messaging, from one familiar language straight into another, and MT is the automatic conversion of text/speech from one language to a different (Kunchukuttan, 2006 as cited in Marito \& Ashari, 2017). Ghazala asserts that translation includes both the processes similarly because translators' methods to convey the meaning. He rightly states that for an accurate and appropriate translation, translators need to understand the meaning of the source text fully. In line with him, all aspects of language like meaning, grammar, style, and sounds enjoy equal importance within the translation, where failing to watch anybody of them will cause distorting of meaning (Hassan, 2020). These new utterly different from traditional translation models have also expedited what translators do since they need accelerating the interpretation method and redoubled productivity still as developing cooperation skills (Pym, 2003). They, thus, can use MT to assist them in meeting such demands, as MT systems can save them time and effort. 
MT systems will be wont to provide rough translations that might be post-edited by translators to provide an accurate translation (Sabtan, 2020). As emphasized before, the blending of the technology into the interpretation teaching has modified the means translator follows throughout the interpretation method, which influenced the abilities expected of them (Odacioglu \& Kokturk, 2015).

\section{B. RESEARCH METHOD}

This study applied qualitative descriptive research method. Qualitative research method is called as a new method, because its popularity is new, planted post positivistic because based on the philosophy of post positivism (Sugiyono, 2018). This method is also referred to as an artistic method, because research is more sebi (less patterned), and is called an interpretive method because the research results are more concerned with the interpretation of data found in the field. In addition that qualitative strategies have faith in text and image knowledge, have distinctive steps in $\mathrm{k}$ nowledge analysis, and draw on numerous styles (Creswell, 2009).

This research was conducted at the sixth and seventh semester of English Department students of Megarezky University. The total number of students as the sample in this study were 13 students who had studied translation subject.

The survey of student perception was managed by online-questionnaire (Google form). The questionnaire consisted of 18 closed-ended questionnaires that allow for indepth information from the students' perception on utilizing Machine Translation (MT). The data collection can be divided into six sections that draw the students' perception on importance of English subject matters in translation; students' experience on translation assignment, the utility of translation skill; most popular translation ways and material; translation learning methods; students' disposition and course length expectation. With intensive literature review, a table of specification with the initial things was created to guide item construction for developing the dimensions; we tend ready to establish students' perception and expectation on translation in teaching and learning process.

The responses were analyzed as Bodgan 1998 states in (Sugiyono, 2018) data analysis is the process of systematically searching and arranging the interview transcripts, field notes, and different materials that you just accumulate to extend your 
own understanding of them and to change you to gift what you have got discovered to others.

\section{FINDINGS AND DISCUSSION}

\section{Findings}

After collecting data by using questionnaires, the researcher got the results of this research through some data as follows:

\section{Q1. Have you ever used machine translation?}

The students chose yes. It means that machine translation enables students to translate sentence or words from source language to target language.

\section{Q2. How often do you use the machine translation?}

The students dominantly use machine translation when they find difficult words. They can know part of speech of the words so that they can place right words into target language.

\section{Q3. Have you ever used machine translation online based?}

Actually the students have ever used machine translation such as google tran slate. It is easy to acces it. The students can get the result of translation although they have to rearrange grammar manually.

Q4. What type of language do you generally search for in a Machine Translation?

Type of language generally used are English-Indonesian and Indonesian-English. Sometimes, students type Indonesian (source language) then translate into English (target language) and vise-versa.

\section{Q5. Have you used translation as a learning devices or tools?}

The students used translation as a learning devices or tools to enable in translating difficult words. Generally, they use it when finding unfamiliar words.

\section{Q6. Does machine translation help you on translation class?}

The students chose machine translation that can help translating words including unfamiliar words. Machine translation providing the result of translation fast. Sometimes, assignment can be finished by using machine translation in the class.

\section{Q7. What is the role of machine translation for you?}

Students used machine translation because it helps to translate from source language to 
target language fast and find the new words including unfamiliar words.

Q8. Do you find it easy to use?

Students think that machine translation can be used everywhere and anywhere. These can be used in offline so that students are not worry to use this machine translation.

Q9. How is importance machine translation on your English studies?

The machine translation helps for students. They can know the meaning of unfamiliar word and translate both into Indonesian-English and into English-Indonesian. This machine translation is very important for students.

Q10. What are the benefits of using machine translation?

The machine translation gives benefits for students especially in translation subject. Students can search unfamiliar word fast, help in translating long sentence, easy and simple to use it.

Q11. What is the easier one between English- Indonesian and Indonesian English translation?

Students always use English-Indonesian through machine translation. These is flexible, automatically words appear into target language. In addition, there are part of speech and sound.

Q12. What are the effects use Machine translations?

Students chose machine translation that help to find more words as a positive effect and negative effect is to decrease their interest to open dictionary. In addition, machine translation can help students to solve the problem in English.

Q13. Does Machine translation reduce the interest on learning English?

Machine translation can not reduce students' interest on learning Eglish. This can help students to increase new vocabulary.

Q14. Which one do you usually use Online or Offline Machine Translation?

Students install offline machine translation. It is caused that this machine can be used anywhere although inadequate network.

Q15. Can you find all of the words that you are looking for in Machine Translation?

Students sometimes find all words needed through machine translation. One thing that make difficult to find it is terms.The students should find in other references.

Q16: What are the problems that usually faced on using machine translation? 
Students think that there is a problem when using machine translation. One of them is no correlation meaning and incorrect grammar found in the result of translation. There is translation of word by word.

\section{Q18. What will you do to solve if you found the different result of machine} translation from the principle of translation?

When students found different result of machine translation, they recheck and rearrange to get a good translation by their own understanding. Furthermore, they ask the expert and friends.

\section{Discussion}

Data of questionnaires were collected and processed, the researcher got some results. These describe that all of EFL students had ever utilized Machine Translation (MT). They required machine translation for various reasons to use it. They used it for the aims; to identify all meanings that they wanted to know, it indicated that they suspected about their vocabulary mastery. The students applied machine translation when they found difficult or unfamiliar words to translate into target language. This machine enables students to provide new words as new vocabulary for students. Machine translation commonly used by students are google translate and offline dictionary. This machine was used as instead of dictionary in which it can be used anywhere and everywhere.

EFL students who had no confidential and efforts to complement their vocabulary, they simply relied on MT. Students rechecked and rearranged to get a good translation by their own understanding. They utilized MT to translate, word, phrase, sentence, paragraph, and even text. it absolutely was hazardous for them, because it could make them be hit or killed by MT, it absolutely was not a decent situation for them as students of English education department, also it absolutely was harmful for them after they had to try and do direct conversation where there was no time to browse internet about which one do you usually use Online or Offline Machine Translation? Their response was using offline MT was better than offline MT. Most of students utilized computational linguistics or Machine Translation when they found the difficult and new words. Their answers were more dominant on looking for English and Indonesian. But when the researcher asked about Is the language utilized in Machine Translation simple to comprehend? They responded sometimes it meant that they did 
not comprehend all the words that searched. They translated some word by using MT need more investigation because the researcher was out of control the sort of word that they translated the simple familiar word or unfamiliar words. It becomes as a phenomenon too, because they said that all of students utilized MT to translate word by word. When it is compared to the theory of translation, it had been not the most effective translation result, because context can change the meaning of word. Using MT was helpful. supported the students' answers, its most useful laid on the practice, it was relevance with Rossi \& Chevrot (2019) stated that perceptions of MT have a strong impact on both perceived usefulness and actual use. By using MT, they might get a description meaning about, words, phrases, sentences, or maybe paragraphs faster than looking up dictionary. It meant that the students put MT as another variety of dictionary and as a comparison translation result. They assumed that English Indonesian was easier than Indonesian - English translation. It could be predicted because Indonesian is their own language, in order that they might predict the meaning supported the sentence context. So, this answer was influenced by the language richness of the users. Then when the researcher asked about What is the role of machine translation for you? They answered MT helped to translate and to find the new words, both of options were same because MT was easy to use.

Based on the students' answer, the consequences of using MT, there were three; positive, negatives and no effects, the effect of using MT, and they knew that MT had the positive effect it helps to find more words and negative effect is it decrease our interest to open dictionary and The result of translation sometimes irrelevant. So the positive side, it focused on practicing. They got a general description about acceptation, it just needed context understanding, but MT leaded them to a confused situation, because sometimes did not have correlation meaning and incorrect grammar from what they knew and it was difficult to use if there was no network. It made them confused deciding the proper one. Beside it, they said that dictionary made them became lazier to open it. This dependence made them lazy to memorize new words. and therefore, the last was no effect, but the researcher are doubt about this answer, it is going to be caused by their unsureness a few researches. It made two different answers that MT can reduce learning interest; yes and no. 
All of the words may be found in MT, but it was debatable. Because they were not asked further about styles of word, they were searching by using MT. Meanwhile a number of them answered yes, it's same as too or they were searching the word not meaning by using key words. It means it becomes because the next work to create it more detail. Actually, the issues would be faced during MT, it depends the user to resolve it, for example; grammar and structure, style of words and meaning. they will be solved by the user knowledge. So, when the solution was no problem, so it may be predicted that the user was superb or very bad in English. it had been good once they could connect the interpretation text into the context, meanwhile it had been very bad because they did not know the correct one, or in another word that they had no choice unless accepted it. the funny answer was due to losing internet connectivity, and it had been unacceptable answer. to resolve the issues they faced, they consulted them to dictionary. Even though they sometimes faced some problems or difficulties, they assumed that MT was very useful, because it could make their task easier and more practice by having a general meaning of a translation text, further they use dictionary made it clearer. And after knowing the effect of Machine Translation (MT), the students just used it if it was necessary, So they knew MT was not too important for them. Also, it can be seen in table 20 about what will you do to solve if you found the different result of machine translation from the principle of translation? The students' response was rechecked and rearranged to get a good translation by their own understanding, Ask the expert and friends and check it back and find in dictionary. So that EFL students in the sixth and seventh semester of English education department Universitas Megarezky in translating words, phrase, text, paragraph has to recheck and rearrange to get a good translation by their own understanding and ask the experts or their friends because MT sometimes did not have correlation meaning and incorrect grammar from what they knew.

\section{CONCLUSIONS}

Based on description above, it can be concluded that as the product of technology, Machine Translation (MT) becomes another option to recognize the meaning of foreign language. Machine Translation can be used as dictionary, too. MT is incredibly useful and helpful, it can provide a general description to the users, it gives an inspiration or consideration to the users to understand the meaning. So that, 
EFL students in the sixth and seventh semester of English education department Universitas Megarezky in 2019/2020 academic year in EFL students' perception to translate. MT sometimes do not have correlation meaning and incorrect grammar from what they know in translating words, phrase, text, paragraph has to recheck and arrange to induce a decent translation by their own and live a private student's perception of an entire category, as distinct from students' perception of their own roles within the classroom and out the classroom in translating by Machine Translation (MT). Then, MT basically can be used not only for translating. MT too can be used to learn sounds or pronunciation. And for further research, it is recommended to be able to analyze in depth about the results of translations by MT conducted by students. This matter provides feedback and consideration of students' perception. 


\section{REFERENCES}

Alkhatnai, M. (2019). Instant Mobile Messaging (WhatsApp) and Teaching Translation: Views Elicited from Saudi Translation Teachers and Students. International Journal of English Linguistics, 9(5), 98. https://doi.org/10.5539/ijel.v9n5p98.

Bhattacharyya, P., \& Jha, S. K. (2016). A Survey report on Evolution of Machine Translation. January 2017.

Carrió-Pastor, M. L. (2016). Technology Implementation in Second Language Teaching and Translation Studies. New Frontiers in Translation Studies, June 2016. https://doi.org/10.1007/978-981-10-0572-5.

Creswell, J. W. (2009). Research Design: Qualitatif, Quantitative, and Mixed Methods Approaches. Third Edition (Terjemahan) 2013 Research Design: Pendekatan Kualitatif, Kuantitatif, dan Mixed. (Third Edit). Yogyakarta: Pustaka Pelajar.

Davidoff, L. L. (1998). Psikologi Suatu Pengantar. Erlangga.

Hassan, A. Q. A. (2020). Translation Strategies Employed by EFL Learners and the Impact of That on Their Translation Skills Development. International Journal of English Linguistics, 10(4), 34. https://doi.org/10.5539/ijel.v10n4p34.

Le, T. K. Van, \& Dao, T. M. T. (2019). An investigation into students' perception of utilizing online dictionaries in translationinterpretation. Espacios, 40(39).

Marito, S., \& Ashari, E. (2017). Efl Students' Perception About Machine Translation. Jurnal Dimensi, 6(2), 256-269. https://doi.org/10.33373/dms.v6i2.1050.

Odacioglu, M. C., \& Kokturk, S. (2015). The Effects of Technology on Translation Students in Academic Translation Teaching. Procedia - Social and Behavioral Sciences, 197(February), 1085-1094. https://doi.org/10.1016/j.sbspro.2015.07.349.

Pym, A. (2003). Redefining translation competence in an electronic age. In defence of a minimalist approach. Meta, 48(4), 481-497. https://doi.org/10.7202/008533ar.

Rossi, C., \& Chevrot, J. P. (2019). Uses and perceptions of machine translation at the European Commission. Journal of Specialised Translation, 31, 177-200.

Sabtan, Y. M. N. (2020). Teaching Arabic Machine Translation to EFL Student Translators: A Case Study of Omani Translation Undergraduates. International Journal of English Linguistics, 10(2), 184. https://doi.org/10.5539/ijel.v10n2p184. 
Sugiyono. (2018). Metode Penelitian Kuantitatif,. Bandung: Alfabeta.

Tsai, S. C. (2019). Using google translate in EFL drafts: a preliminary investigation. Computer Assisted Language Learning, 32(5-6), 510-526. https://doi.org/10.1080/09588221.2018.1527361 